\title{
Prebiotic and antimicrobials on performance, carcass characteristics, and antibody production in broilers
}

\author{
Prebiótico e antimicrobianos sobre o desempenho, características \\ de carcaça e produção de anticorpos em frangos de corte
}

\author{
Maíra Fomentini ${ }^{\mathrm{I}}$ Douglas Haese ${ }^{\mathrm{I}^{*}}$ João Luís Kill ${ }^{\mathrm{I}}$ Rodrigo Pereira Sobreiro \\ Débora Del Puppo I Ismail Ramalho Haddade ${ }^{I I}$ Anderson Lazarini Lima ${ }^{\text {III }}$ Alysson Saraiva ${ }^{\text {IV }}$
}

\section{ABSTRACT}

To evaluate the effect of supplementation with mannan oligosaccharides, avilamycin and halquinol, alone or in combination, on the performance, carcass characteristics and antibody production in broilers (1-49 days old), male broiler chicks (n=1440; Cobb 500; one day old) were housed and distributed into a completely randomized design into six treatments (eight replicates; 30 animals per pen). To produce the experimental diets, three types of performance enhancer additives were used. Halquinol (HAL), avilamycin (AVI) and mannan oligosaccharides (MOS) were included (alone or in combination) in the basal diet (instead of corn starch). Effects of diet were observed on results of animal performance in the period 1-21 and 1-42 days old. Broilers fed with a diet without growth promoter showed lower weight gain in relation to those fed with diets with antimicrobials, MOS or a combination of them. In the period 1-49 days old, feed conversion increased in broilers fed with rations without promoter. At the end of the experimental period no influence of diets was observed on the carcass yield and cuts, and titles of specific antibodies to avian infectious bronchitis. The use of MOS and/or antimicrobials (AVI or $H A L)$, alone or in combination, improves feed conversion of broilers reared until 49 days of age.

Key words: avilamycin, additive, halquinol, mannan oligosaccharides

RESUMO

Para avaliar o efeito da suplementação com mananoligossacarídeo, avilamicina e halquinol, isoladamente ou combinados, sobre o desempenho, características de carcaça e produção de anticorpos em frangos de corte (1-49 dias de idade), pintos machos de corte ( $n=1440$; linhagem Cobb 500; idade: um dia) foram alojados e distribuídos em delineamento experimental inteiramente casualizado com seis tratamentos (oito repetições; 30 animais por unidade experimental). Para compor as rações experimentais, três tipos de aditivos melhoradores de desempenho foram usados. Halquinol (HAL), avilamicina (AVI) e mananoligossacarídeo (MOS) foram incluídos (isoladamente ou em associação) na ração basal (em substituição ao amido de milho). Foi observado efeito das rações sobre os resultados de desempenho dos animais no período 1-21 e 1-42 dias de idade. As aves alimentadas com ração sem melhorador de desempenho apresentaram menor ganho de peso em relação àquelas que consumiram rações com antimicrobianos, MOS ou uma combinação deles. No período 1-49 dias de idade, a conversão alimentar aumentou nas aves alimentadas sem melhorador de desempenho. No final do periodo experimental, não foi observado efeito das rações sobre o rendimento de carcaça e cortes e títulos de anticorpos especificos contra bronquite infecciosa aviária. A utilização de mananoligossacarídeo elou antimicrobianos (avilamicina e halquinol), isoladamente ou combinados, melhora a conversão alimentar de frangos de corte criados até 49 dias de idade.

Palavras-chave: avilamicina, aditivo, halquinol, mananoligossacarídeo.

\section{INTRODUCTION}

Currently, there is a major concern in the society with the use of antimicrobial agents in livestock feed, and such chemicals can be added to the feed as either therapeutic agents or performance enhancers. As enhancers, lower antimicrobial doses are used for longer periods, which can potentiate selection of resistant bacteria (BAURHOO et

\footnotetext{
'Programa de Pós-graduação em Ciência Animal, Universidade Vila Velha (UVV), 29102-606, Vila Velha, ES, Brasil. E-mail: douglas.haese@uvv.br. "Corresponding author.

IIInstituto Federal do Espírito Santo, Santa Lucia, ES, Brasil.

IIIAlltech do Brasil, São Pedro do Ivaí, PR, Brasil.

${ }^{\mathrm{IV}}$ Universidade Federal de Viçosa (UFV), Viçosa, MG, Brasil. 
al., 2009). For this reason, a great pressure has been exerted by the society to reduce the use of antimicrobials in the livestock feed. In Europe, antibiotic use as performance enhancers is prohibited since 2006, due to the concern about transfer of microorganism with antibiotic-resistant genes from animal to human microbiota (CASTANON et al., 2007). Conversely, it should be taken into account that use of antimicrobials as performance enhancers improves animal performance (MILES et al., 2006) due to its action on pathogenic bacteria, which improves feed conversion, daily weight gain, uniformity, and carcass yield.

The need to increase efficiency in broiler industry, the threat of selection of resistant bacteria, and global demand for safe food has promoted a search for alternatives to antimicrobials use as performance enhancers in broiler production. In this context, the interest in the use of prebiotics has increased. According to ALBINO et al. (2006) the prebiotics use could eliminate problems as bacterial resistance and antimicrobial residues in poultry products, besides improving the image of products regarding the consumer market.

Mannan oligosaccharides (MOS) are yeast wall-derived prebiotics that can bind to the fimbriae of pathogenic Gram-negative bacteria such as $\boldsymbol{E}$. coli and Salmonella spp. Such binding causes pathogenic bacteria to be eliminated from the intestinal lumen, as they cannot adhere to the epithelial surface of enterocytes. Benefits of including MOS in diets for broiler chickens come from the change in their intestinal microbiota and decrease in the turnover rate of their intestinal tract. Besides, addition of MOS results in an increased production of immunoglobulins (Ig) in broilers and laying hens (SHASHIDHARA \& DEVEGOWDA, 2003). Despite these benefits, the use of MOS instead of antimicrobials as performance enhancer has shown inconsistent results (ALBINO et al., 2006; BAURHOO et al., 2009; KIM et al., 2011). Thus, the objective of this study was to evaluate the effect of supplementation with MOS, avilamycin, and halquinol, alone or in combination, on performance, carcass characteristics and antibody production in broilers in the period 1-49 days old.

\section{MATERIALS AND METHODS}

The experiment was conducted in an experimental farm (Centro de Tecnologia Animal Ltda./Center for Animal Technology Ltd.) located in the city of Domingos Martins, state of Espírito Santo (ES), Brazil. Male broiler chicks ( $\mathrm{n}=1440$; Cobb 500 strain; one-day old) were used. Birds were vaccinated against the Marek's and avian Bouba diseases.

The experiment was conducted in a facility with concrete floor; covered with fiber cement tiles (3.0-m height ceiling); lateral short walls $(0.5-\mathrm{m}$ height), closed laterally with wire mesh $(3.0 \mathrm{~cm})$, adjustable external curtains (braided polyethylene), at experimental unit $(1.5 \times 1.5 \mathrm{~m})$ to approach the challenges to the maximum, which usually occur during poultry growth.

In order to promote a conventional management in a commercial farm, the birds were housed in boxes with wood shaving beds (10-cm thick), which were reused for two consecutive batches of broiler raising. A continuous (24-h; natural and artificial) light program was used.

In each phase (Table 1), the basal diet without performance enhancers was formulated based on corn and soybean meal, and supplemented with industrial amino acids to meet the aminoacidic proportions recommended by ROSTAGNO et al. (2011) based on the ideal protein. Feed and water were provided ad libitum.

Broilers were distributed in a completely randomized design into six treatments, eight replicates and 30 birds per pen. Three types of performance enhancing additives, halquinol (HAL), avilamycin (AVI) and mannan oligosaccharides (MOS) were added to the diets, alone or in combination, replacing corn starch to compose the experimental diets in the growth (1-21 days), termination (22-42 days) and preslaughter (43-49 days) phases. The experimental diets were composed according to table 2 . The performance data were obtained in the cumulative periods 1-21, 1-42, and 1-49 days old. They are as follows: weight gain, feed intake (obtained by the difference between total feed provided and leftovers collected at the end of each period, based on the average number of birds), feed conversion (calculated by dividing the total feed consumed by the weight gain, corrected for the weight of dead birds), viability (calculated by dividing the total chickens withdrawn by the chicks received, multiplied by 100), and productive efficiency index (PEI; calculated by multiplying the daily weight gain by viability, divided by the feed conversion, and multiplied by 100).

At the $49^{\text {th }}$ day, after six hours of feed fasting, two birds were slaughtered by cervical dislocation and selected according to the average weight of each pen $( \pm 10 \%$ of the average weight $)$ to evaluate the carcass yield and prime cuts (breast, drumstick, and thigh). The carcasses were weighed without head, feet, viscera and abdominal fat. The 
Table 1 - Percentage and calculated composition of basal diet.

\begin{tabular}{|c|c|c|c|}
\hline Ingredients (\%) & $\begin{array}{l}1-21 \\
\text { days }\end{array}$ & $\begin{array}{c}22-42 \\
\text { days }\end{array}$ & $\begin{array}{c}43-49 \\
\text { days }\end{array}$ \\
\hline Corn bran & 52.400 & 58.378 & 72.942 \\
\hline Soy bean meal & 40.150 & 34.451 & 22.047 \\
\hline Soybean oil & 3.630 & 4.177 & 2.720 \\
\hline Phosphate, dicalcium & 1.640 & 1.204 & 0.788 \\
\hline Limestone, calcitic & 0.930 & 0.757 & 0.626 \\
\hline Sodium chloride (common salt) & 0.490 & 0.395 & 0.361 \\
\hline L-Lysine. $\mathrm{HCl}(78 \%)$ & 0.150 & 0.141 & 0.202 \\
\hline DL-Methionine (98\%) & 0.300 & 0.232 & 0.148 \\
\hline L-Threonine (98\%) & 0.040 & 0.015 & 0.016 \\
\hline${ }^{1}$ Premix, Vitamin & 0.120 & 0.100 & 0.100 \\
\hline${ }^{2}$ Premix, Mineral & 0.050 & 0.050 & 0.050 \\
\hline Cornstarch & 0.100 & 0.100 & 0.100 \\
\hline Avilamycin (10\%; AVI) & - & - & - \\
\hline Halquinol ( $60 \%$; HAL) & - & - & - \\
\hline${ }^{3}$ Mannan oligosaccharide (MOS) & - & - & - \\
\hline \multicolumn{4}{|l|}{ Calculated composition } \\
\hline Energy, metabolizable, $\mathrm{kcal} / \mathrm{kg}$ & 3,020 & 3,174 & 3,250 \\
\hline Protein, crude, $\%$ & 22.60 & 21.00 & 16.60 \\
\hline Lysine, digestible, $\%$ & 1.250 & 1.100 & 0.862 \\
\hline Methionine + Cystine, digestible, $\%$ & 0.900 & 0.804 & 0.629 \\
\hline Threonine, digestible, $\%$ & 0.810 & 0.715 & 0.560 \\
\hline Valine, digestible, $\%$ & 0.960 & 0.858 & 0.672 \\
\hline Tryptophan, digestible, $\%$ & 0.259 & 0.229 & 0.164 \\
\hline Isoleucine, digestible, $\%$ & 0.897 & 0.802 & 0.598 \\
\hline Leucine, digestible, \% & 1.752 & 1.624 & 1.359 \\
\hline Arginine, digestible, $\%$ & 1.451 & 1.291 & 0.947 \\
\hline Glycine + Serine, digestible, $\%$ & 1.908 & 1.368 & 1.313 \\
\hline Calcium, $\%$ & 0.870 & 0.717 & 0.528 \\
\hline Available Phosphorus (\%) & 0.420 & 0.335 & 0.246 \\
\hline Sodium $(\%)$ & 0.210 & 0.198 & 0.180 \\
\hline
\end{tabular}

${ }^{1}$ Vitamin supplements (nutrients per $\mathrm{kg}$ of product): Vitamin A: 9,000,000 I.U., Vitamin $\mathrm{D}_{3}$ : 2,500,000I.U., Vitamin E: 20,000mg, Vitamin $\mathrm{K}_{3}: 2500 \mathrm{mg}$, Vitamin $\mathrm{B}_{1}: 1500 \mathrm{mg}$, Vitamin $\mathrm{B}_{2}: 6000 \mathrm{mg}$, Vitamin $\mathrm{B}_{6}$ : $3000 \mathrm{mg}$, Vitamin $\mathrm{B}_{12}: 12 \mathrm{mg}$, Folic acid: $800 \mathrm{mg}$, Niacin: 25,000mg, Pantothenic acid: 12,000mg, Selenium: 250mg, Biotin: $60 \mathrm{mg}$; ${ }^{2}$ Mineral supplements (nutrients per $\mathrm{kg}$ of product): Copper: $20,000 \mathrm{mg}$, Iron: $100,000 \mathrm{mg}$, Iodine: $2000 \mathrm{mg}$, Manganese: 160,000mg, Zinc: 100,000mg, Cobalt: 2000mg; 3 Actigen $^{\circledR}: 280 \mathrm{~g} \mathrm{~kg}^{-1}$ crude protein $(100 \%$ yeast cell wall).

yield of carcass and noble parts were calculated in relation to the live weight before slaughter.

To evaluate production of immunoglobulin $\mathrm{G}(\mathrm{IgG})$ against infectious bronchitis, the birds were sensitized by vaccination via drinking water on the $7^{\text {th }}$ and $21^{\text {st }}$ days old. The birds were submitted to water fasting two hours before vaccination. At 49 days of age, blood samples were collected (brachial vein puncture; two animals per pen) and centrifuged, and serum was analyzed for IgG concentration. As absorbance $(\lambda=450 \mathrm{~nm})$ is directly proportional to
Table 2 - Inclusion of additives (in ppm) in experimental diets consumed by broilers during the growth, termination, and pre-slaughter phases.

\begin{tabular}{llcl}
\hline $\begin{array}{l}\text { Feed containing } \\
\text { additives }\end{array}$ & Growth & Termination & Pre-slaughter \\
\hline Without enhancer & - & - & - \\
AVI & 8 & 6 & - \\
MOS & 400 & 200 & 200 \\
AVI + MOS & $8: 400$ & $6: 200$ & $0: 200$ \\
AVI + HAL & $8: 15$ & $6: 15$ & - \\
AVI + HAL + MOS & $8: 15: 400$ & $6: 15: 200$ & $0: 0: 200$ \\
\hline
\end{tabular}

the logarithm of IgG concentration, the absorbance readings obtained in the samples were considered estimates of IgG. A commercial kit (FlockCheck IBD/NDV antibody ELISA) was used for analysis.

Statistical analyzes of data were performed using the general linear model (GLM) procedure (SAS Institute, 2009). Mean values were compared using the Student-Newman-Keuls (SNK) test at 5\% probability.

\section{RESULTS AND DISCUSSION}

An effect $(\mathrm{P}<0.05)$ of feed was observed on the results of animal performance in the period 1-21 days old (Table 3). Birds fed with diet without performance enhancer presented lower weight gain and worse feed conversion compared to those fed with diets with antimicrobials, MOS or a combination of them. Similarly, ALBINO et al. (2006) reported a decrease $(\mathrm{P}<0.05)$ in weight gain of birds fed without performance enhancer compared to those fed with diet containing AVI (7ppm). However, the same authors observed no increase in weight gain with addition of MOS (0.2\%). BAURHOO et al. (2009) reported no improvement in weight gain, feed intake and feed conversion with addition of virginiamycin $\left(16.5 \mathrm{mg} \mathrm{kg}^{-1}\right)$ and bacitracin $\left(55.0 \mathrm{mg} \mathrm{kg}^{-1}\right)$ or MOS ( 0.2 and $0.5 \%$ ) compared to the control diet in the period 1-21 days old.

Regarding feed conversion, SMITH (2011) reported that use of diet without antibiotics decreases uptake of nutrients and reduces weight gain. Results of the present study are in agreement with those of SMITH (2011), since lower weight gain and increased feed conversion $(\mathrm{P}<0.05)$ were observed in animals that consumed diet without performance enhancer. The use of the same chicken litter in two consecutive batches may be linked to such lower performance. Because of worsening in weight gain and feed 
Table 3 - Weight, weight gain (WG), feed intake (FI), feed conversion (FC), viability (VI), and productive efficiency index (PEI) of broiler chickens at different experimental phases as a function of diets.

\begin{tabular}{|c|c|c|c|c|c|c|c|c|}
\hline Parameters & Without enhancer & AVI & MOS & AVI + MOS & $\mathrm{AVI}+\mathrm{HAL}$ & $\mathrm{AVI}+\mathrm{MOS}+\mathrm{HAL}$ & $\mathrm{P}$ values & CV $(\%)$ \\
\hline \multicolumn{9}{|c|}{ 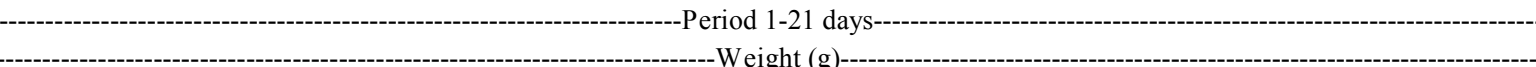 } \\
\hline 01 day & 46.1 & 45.7 & 46.0 & $\begin{array}{l}----W \text { eight }(g) \\
\quad 45.6\end{array}$ & 45.5 & 45.7 & 0.138 & 1.15 \\
\hline 21 days & $786.7^{b}$ & $905.3^{\mathrm{a}}$ & $915.3^{a}$ & $934.5^{\mathrm{a}}$ & $922.4^{\mathrm{a}}$ & $954.0^{\mathrm{a}}$ & 0.001 & 3.27 \\
\hline WG (g) & $740.4^{b}$ & $860.0^{\mathrm{a}}$ & $869.3^{a}$ & $888.9^{a}$ & $876.9^{\text {a }}$ & $908.2^{\mathrm{a}}$ & 0.013 & 3.45 \\
\hline $\mathrm{FI}(\mathrm{g})$ & $1283^{a}$ & $1244^{\mathrm{ab}}$ & $1213^{\mathrm{ab}}$ & $1190^{\mathrm{b}}$ & $1228^{\mathrm{ab}}$ & $1215^{\mathrm{ab}}$ & 0.001 & 3.51 \\
\hline $\mathrm{FC}(\mathrm{g} / \mathrm{g})$ & $1.73^{\mathrm{a}}$ & $1.45^{\mathrm{b}}$ & $1.40^{\mathrm{b}}$ & $1.34^{\mathrm{b}}$ & $1.40^{\mathrm{b}}$ & $1.34^{\mathrm{b}}$ & 0.001 & 5.37 \\
\hline VI & 96.7 & 97.7 & 98.5 & 98.4 & 97.4 & 97.1 & 0.245 & 2.30 \\
\hline PEI & $198^{\mathrm{a}}$ & $280^{b}$ & $294^{b}$ & $313^{b}$ & $295^{b}$ & $321^{b}$ & 0.001 & 8.80 \\
\hline 01 day & 46.1 & 45.7 & 46.0 & 45.6 & 45.5 & 45.7 & 0.138 & 1.15 \\
\hline 42 days & $2566^{\mathrm{b}}$ & $2664^{\mathrm{a}}$ & $2679^{a}$ & $2744^{\mathrm{a}}$ & $2736^{\mathrm{a}}$ & $2.733^{\mathrm{a}}$ & 0.001 & 2.53 \\
\hline WG (g) & $2519^{b}$ & $2619^{a}$ & $2633^{a}$ & $2699^{\mathrm{a}}$ & $2690^{\mathrm{a}}$ & $2.687^{\mathrm{a}}$ & 0.049 & 2.57 \\
\hline $\mathrm{FI}(\mathrm{g})$ & 4712 & 4727 & 4680 & 4517 & 4656 & 4598 & 0.001 & 2.52 \\
\hline $\mathrm{FC}(\mathrm{g} / \mathrm{g})$ & $1.87^{\mathrm{a}}$ & $1.81^{\mathrm{ab}}$ & $1.78^{\mathrm{abc}}$ & $1.68^{\mathrm{c}}$ & $1.73^{\mathrm{bc}}$ & $1.71^{\mathrm{bc}}$ & 0.001 & 3.93 \\
\hline VI & $93.2^{\mathrm{b}}$ & $96.2^{\mathrm{a}}$ & $96.8^{\mathrm{a}}$ & $97.1^{\mathrm{a}}$ & $96.8^{\mathrm{a}}$ & $97.4^{\mathrm{a}}$ & 0.001 & 3.40 \\
\hline PEI & $300^{c}$ & $333^{b}$ & $341^{\mathrm{ab}}$ & $373^{a}$ & $357^{\mathrm{ab}}$ & $364^{\mathrm{ab}}$ & 0.001 & 6.30 \\
\hline 01 day & 46.1 & 45.7 & 46.0 & 45.6 & 45.5 & 45.7 & 0.138 & 1.15 \\
\hline 49 days & 3128 & 3243 & 3261 & 3243 & 3236 & 3247 & 0.134 & 2.65 \\
\hline WG (g) & 3081 & 3197 & 3214 & 3197 & 3190 & 3201 & 0.165 & 2.69 \\
\hline $\mathrm{FI}(\mathrm{g})$ & 5968 & 5990 & 5920 & 5803 & 5938 & 5876 & 0.131 & 2.69 \\
\hline $\mathrm{FC}(\mathrm{g} / \mathrm{g})$ & $1.94^{\mathrm{a}}$ & $1.87^{\mathrm{b}}$ & $1.84^{\mathrm{b}}$ & $1.82^{b}$ & $1.86^{\mathrm{b}}$ & $1.84^{\mathrm{b}}$ & 0.009 & 2.67 \\
\hline VI & $93.0^{\mathrm{b}}$ & $96.2^{\mathrm{a}}$ & $96.5^{\mathrm{a}}$ & $96.8^{\mathrm{a}}$ & $95.3^{\mathrm{a}}$ & $97.0^{\mathrm{a}}$ & 0.001 & 3.80 \\
\hline PEI & $302^{b}$ & $336^{\mathrm{a}}$ & $344^{\mathrm{a}}$ & $349^{\mathrm{a}}$ & $337^{\mathrm{a}}$ & $346^{\mathrm{a}}$ & 0.001 & 4.68 \\
\hline
\end{tabular}

Average values followed by different letters in the same line differ by the SNK test at 5\% probability.

conversion a decrease $(\mathrm{P}<0.05)$ was observed in the productive efficiency index.

However, the results of various authors (ALBINO et al., 2006; BAURHOO et al., 2009; KIM et al., 2011) are inconsistent with each other relative to the use of performance enhancers. Such differences between results may be associated with the degree of sanity on the farm, specificity of the performance enhancer, dose, age, type of bacterial challenge (quantity, species, and virulence) and management.

Despite the lower weight gain and worsening in feed conversion in animals fed control diet, difference $(\mathrm{P}>0.05)$ was not observed in feed intake between treatments, except between the association of AVI + MOS, which differed $(\mathrm{P}>0.05)$ from the control diet. This lower feed intake could be related to increased absorption of nutrients (energy) compared to the control diet, since feed conversion was also lower (1.34 vs 1.73). According to LEESON et al. (1996) the broiler possesses a good ability to control its feed intake based on energy intake.

An effect of $(\mathrm{P}<0.05)$ diets was observed on weight gain and viability in the period 1-42 days old (Table 3). Birds fed control diet presented weight gain and viability lower than those of $(\mathrm{P}<0.05)$ birds fed with antimicrobial diets, MOS or their combination. Similar results for weight gain were obtained by ALBINO et al. (2006) with addition of AVI in the periods $1-21(7 \mathrm{ppm})$ and $22-42(5 \mathrm{ppm})$ days old and use of MOS $(0.2 \%)$, alone or in combination with AVI. Conversely, OLIVEIRA et al. (2009) reported that difference was not found between feed added with MOS or antimicrobials in the performance of broilers at 42 days of age. MUNYAKA et al. (2012) also reported no effect on the performance of broiler chickens with the use of MOS or bacitracin compared to the control diet in the 1-42 day old period.

In feed conversion, although difference was not reported between control diet and diets 
containing the antimicrobial AVI and MOS alone in the 1-42 day of life, period it was possible to verify that combination of different performance enhancers (AVI + MOS, AVI + HAL, and AVI + MOS + HAL) reduced $(\mathrm{P}<0.05)$ feed conversion in relation to the diet without the additives.

Reduction in feed conversion probably was possible due to the inclusion of performance enhancers in the diet and their synergistic action on different pathogenic microorganisms that can colonize the gastrointestinal tract. Pathogenic bacteria can present different degrees of virulence and resistance to antimicrobials, and addition to the diet of one or more enhancers with different mechanisms of action is necessary.

Avilamycin acts preferentially on Grampositive bacteria and Halquinol have activity against a wide variety of both Gram-positive and Gram-negative bacteria. Mannan oligosaccharides have action on Gramnegative bacteria that express type-I fimbriae, such as Salmonella spp. and Escherichia coli. Thus, additives which act on different pathogenic microorganisms can promote a synergistic effect on development of broilers.

Regarding on the action of Mannan oligosaccharides MUNYAKA et al. (2012) stated that the differences between results reported in the studies may be due to differences between experimental protocols, production phase, conditions in which the experiment was conducted, source, type, and concentration of MOS used in the additive.

In the total period (1-49 days) of the experiment, effect $(\mathrm{P}>0.05)$ of feed on the weight gain and feed intake by the animals was not observed (Table $3)$. However, feed conversion, viability and PEI worsened $(\mathrm{P}<0.05)$ in birds fed with control diet compared to other treatments, which in turn were similar to each other.

The improvement in feed conversion in animals consuming MOS, antimicrobials or combinations may be due to a more efficient use of nutrients, since no significant difference was observed in weight gain and feed intake. According to MILES et al. (2006), improvement in animal performance with the use of performance enhancer antimicrobials is due to a greater availability of energy for growth and increase in absorption of nutrients, which, in turn, result from reduction in cell proliferation and smaller thickness of mucosa and lamina propria in the intestinal wall.

Effect $(\mathrm{P}>0.05)$ of feed on the carcass and cut yields was not observed (Table 4). Similar results were observed by BAURHOO et al. (2009) who compared feed without performance enhancer and with addition of virginiamycin $\left(16.5 \mathrm{mg} \mathrm{kg}^{-1}\right)$, bacitracin $\left(55.0 \mathrm{mg} \mathrm{kg}^{-1}\right)$ and $\operatorname{MOS}(0.2$ or $0.5 \%)$ reported no difference between the yields of carcass, breast, fillet, drumstick, thigh, and wing at 38 days of age. According to the authors, the similarity between the responses to additives on the final weight of animals may have reduced the effects on carcass and cut yields. In the present study, effect of treatments on the final weight of chickens was also not observed, which is consistent with the statistical similarity between treatments in the carcass and cut yields. Even the improvement in feed conversion $(\mathrm{P}<0.05)$ of animals, which consumed diets with performance enhancers, was not enough to increase their muscle deposition. Similar results were reported by various authors (WALDROUP et al., 2003; PARKS et al., 2005; BAURHOO et al., 2009). Probably, adjustments in the nutritional levels (amino acids and energy) will be necessary to optimize the carcass and cut yields in animals receiving performance enhancers. Effect $(\mathrm{P}>0.05)$ of titers of specific antibodies to avian infectious bronchitis on the treatments was not observed at the end of the experimental period (Table 4). This result is similar to that observed by KIM et al. (2011), who evaluated addition of AVI $\left(6.0 \mathrm{mg} \mathrm{kg}^{-1}\right)$ and MOS (0.025 or $0.050 \%$ ) and reported no significant differences in the $\mathrm{IgG}$ and IgA production in birds with four weeks old. According to SHASHIDHARA \& DEVEGOWDA (2003), diet supplementation with MOS influences the immune system resulting

Table 4 - Effect of diets on carcass and cut yields, and antibody titers to avian infectious bronchitis at 49 days of age.

\begin{tabular}{|c|c|c|c|c|c|c|c|c|}
\hline Variables & Without enhancer & AVI & MOS & AVI + MOS & $\mathrm{AVI}+\mathrm{HAL}$ & $\mathrm{AVI}+\mathrm{MOS}+\mathrm{HAL}$ & $P$ values & CV $(\%)$ \\
\hline Carcass & 73.1 & 72.9 & 72.5 & 73.0 & 72.4 & 72.6 & 0.145 & 2.32 \\
\hline Chest & 36.9 & 37.8 & 36.9 & 36.0 & 36.9 & 38.2 & 0.063 & 7.45 \\
\hline Drumstick & 15.0 & 14.5 & 15.0 & 14.9 & 14.9 & 14.7 & 0.062 & 6.09 \\
\hline Thigh & 15.8 & 15.5 & 14.2 & 15.5 & 16.2 & 16.5 & 0.067 & 15.21 \\
\hline Titers & 2.89 & 2.45 & 2.81 & 2.89 & 2.77 & 2.72 & 0.189 & 19.46 \\
\hline
\end{tabular}


in a significant increase in antibody production. According to these authors, improvement in immune system activation occurs due to an improvement in the absorption of some nutrients such as $\mathrm{Zn}, \mathrm{Cu}$, and Se or all of them both. MUNYAKA et al. (2012) attribute such improvement in the immune system to an increase in the activity of the T and B cells.

Despite the positive effects of the use of MOS on the immune system reported by several authors (SHASHIDHARA \& DEVEGOWDA, 2003; MUNYAKA et al., 2012) in the present study was not observed significant difference $(\mathrm{P}>0.05)$ between treatments on the levels of $\mathrm{IgG}$ to infectious bronchitis. Probably the use of wood shaving beds of two consecutive batches was not sufficient for stimulation of increase in the IgG production by immune system. According MUNYAKA et al. (2012) Low natural challenge or lacks of pathogenic stimulation do not promote activation of B cells for the production of immunoglobulins.

\section{CONCLUSION}

The supplementation of MOS and/or antimicrobial agents (AVI and HAL) alone or in combination no improves carcass characteristics and antibody production in broilers raised until 49 days of age. The feed conversion, viability and productive efficiency index improves with use of MOS and/ or antimicrobial agents (AVI and HAL) alone or in combination in the period of 1-49 days of age.

\section{BIOETHICS AND BIOSSECURITY COMMITTE APPROVAL}

The project of this study was submitted to and approved by the Ethics Committee (CEUA-CTA: 005/2011).

\section{ACKNOWLEDGEMENTS}

We thank Fundação de Administração e Pesquisa Econômico-Social (FAPES) for granting a Master's scholarship to the first author.

\section{REFERENCES}

ALBINO, L.F.T. et al. Use of mannaoligosaccharid based prebiotic in the broiler diets. Revista Brasileira de Zootecnia, v.35, n.3, p.742-749, 2006. Available from: <http://dx.doi.org/10.1590/S151635982006000300015>. Accessed: Nov. 21, 2013. doi: 10.1590/S151635982006000300015 .

BAURHOO, B. et al. Effects of diets containing different concentrations of mannanoligosaccharide or antibiotics on growth performance, intestinal development, cecal and litter microbial populations, and carcass parameters of broilers. Poultry
Science, v.88, n.11, p.2262-2272, 2009. Available from: <http:// ps.oxfordjournals.org/content/88/11/2262>. Accessed: Nov. 25, 2013. doi: $10.3382 /$ ps.2008-00562.

CASTANON, J.I.R. History of the use of antibiotic as growth promoters in European Poultry Feeds. Poultry Science, v.11, n.86, p.2466-2471, 2007. Available from: <http://ps.oxfordjournals.org/ content/86/11/2466. full.pdf + html $>$. Accessed: Apr. 10, 2015. doi: $10.3382 /$ ps.2007-00249.

KIM, G.B. et al. Effect of dietary prebiotic supplementation on the performance, intestinal microflora and immune response of broilers. Poultry Science, v.90, n.1, p.75-82, 2011. Available from: <http://ps.oxfordjournals.org/content/90/1/75>. Accessed: Oct. 10, 2013. doi: 10.3382/ps.2010-00732.

LEESON, S. et al. Broiler response to diet energy. Poultry Science, v.75, n.4, p.529-535, 1996. Available from: <http://ps.oxfordjournals.org/ content/75/4/529>. Accessed: Sept. 10, 2015. doi: 10.3382/ps.0750529.

MILES, R.D. et al. Effect of antibiotic growth promoters on broiler performance, intestinal growth parameters, and quantitative morphology. Poultry Science, v.85, n.3, p.476-485, 2006. Available from: <http://ps.oxfordjournals.org/content/85/3/476>. Accessed: Mar. 12, 2013. doi: 10.1093/ps/85.3.476.

MUNYAKA, P.M. et al. Local and systemic innate immunity in broiler chickens supplemented with yeast-derived carbohydrates. Poultry Science, v.91, n.9, p.2164-2172, 2012. Available from: $<$ http://ps.oxfordjournals.org/content/91/9/2164>. Accessed: Jan. 12, 2014. doi: 10.3382/ps.2012-02306.

OLIVEIRA, M.C. et al. Mananoligossacarídeos e complexo enzimático em dietas para frangos de corte. Revista Brasileira de Zootecnia, v.38, n.5, p.879-886, 2009. Available from: <http:// dx.doi.org/10.1590/S1516-359820090005000174>. Accessed: Jan. 12, 2014. doi: 10.1590/S1516-359820090005000174.

PARKS,C.W.etal. Effects of virginiamycin and mannanoligosaccharidevirginiamycin shuttle program on the growth and performance of large white female turkeys. Poultry Science, v.84, n.12, p.1967-1973, 2005. Available from: <http://ps.oxfordjournals.org/content/84/12/1967>. Accessed: Oct. 12, 2013. doi: 10.1093/ps/84.12.1967.

ROSTAGNO, H.S. Tabelas brasileiras para aves e suínos: composição de alimentos e exigências nutricionais. 3.ed. Viçosa, MG: UFV, DZO, 2011. 252p.

SHASHIDHARA, R.G.; DEVEGOWDA, G Effect of dietary mannan oligosaccharide on broiler breeder production traits and immunity. Poultry Science, v.82, p.1319-1325, 2003. Available from: <http://ps.oxfordjournals.org/content/82/8/1319>. Accessed: Nov. 14, 2013. doi: 10.1093/ps/82.8.1319.

SMITH, J.A. Experiences with drug-free broiler production. Poultry Science, v.90, p.2670-2678, 2011. Available from: <http:// ps.oxfordjournals.org/content/90/11/2670.full>. Accessed: Nov. 12, 2013. doi: $10.3382 / \mathrm{ps} .2010-01032$.

SAS INSTITUTE. SAS/STAT: user's guide. Version 9.2. Cary, 2009. 7869p.

WALDROUP, P.W. et al. Comparison of Bio-Mos ${ }^{\circledR}$ antiobiotic feeding programs in broiler diets containing cooper sulfate. International Journal of Poultry Science, v.2, n.1, p.28-31, 2003. Available from: $<$ http://www.pjbs.org/ijps/fin47.pdf>. Accessed: Apr. 10, 2013. 